therefore, that in batches $B$ and $D$, which produced the higher toxin titres, the lag phase was relatively long while in the poorer batches $A$ and $C$, inoculated with a higher concentration of young organisms, the lag phase was short. In addition to this, the total number of generations in batches $B$ and $D$ would be higher than in $A$ and $C$.

Continuous culture procedures were less successful than the simpler process described above, since the titres obtained did not exceed $40 \mathrm{units} / \mathrm{ml}$. and there was a tendency for the strain to lose toxigenicity.

Since there seems to be some confusion at present as to the units used to evaluate tetanus toxin (due presumably to the change in unit in 1950), it is emphasized that those used here conform to the present international standard.

Wellcome Research Laboratories

Robert O. Thomson

(Biological Division),

Langley Court,

Beckenham, Kent.

${ }^{1}$ Mueller, J. H., and Miller, P. A., J. Immunol., 50, 377 (1945).

2 Mueller, J. H., and Miller, P. A., J. Bact., 67, 271 (1954).

\section{Inhibitory Effect of 5-Hydroxytryptophan on Acid Gastric Secretion}

WE have recently described the effect of 5-hydroxytryptamine on acid gastric secretion elicited by histamine in dogs'. Recent experiments with its procursor 5-hydroxytryptophan have shown that this substance is also capable of inhibiting acid secretion. A technique has been used for recording the secretory-rate from a gastric cannula in anæsthetized dogs, as drops per min. on a kymograph. The acid output is expressed as mille equivalents, and is fairly constant after l hr. during histamine administered by continuous infusion (Table $1, x$ )

Infused 5-hydroxytryptamine rapidly lowers the secretory-rate induced by histamine while with 5-hydroxytryptophan there is a latency before secretory and blood-pressure changes. Whereas 5-hydroxytryptamine led to changes in blood pressure and secretion within $2 \mathrm{~min}$. after starting the infusion, there was a delay of 10-15 min. before similar effects were noticed after starting the 5-hydroxytryptophan infusion. Table $1, b$ illustrates the inhibitory effect of varying doses of 5-hydroxytryptophan, and three experiments are recorded which show a marked fall in acid secretory output elicited by histamine, again delayed until the end of the infusion period. Repeated infusions of 5-hydroxy- tryptophan can be seen to lead to a more prompt inhibition of secretion when given after $2 \mathrm{hr}$. of histamine stimulation than when given earlier after half an hour of secretion. These effects are very similar to those already found in experiments with 5-hydroxytryptamine.

Dalgliesh and Dutton ${ }^{2}$ have recently pointed out that the argentaffin cells of the alimentary tract might be the only source of 5-hydroxytryptophan, the biological precursor of 5-hydroxytrypytamine. The former might be released from this cellular site as a general hormone to be converted locally in various tissue to 5-hydroxytryptamine by specific decarboxylase activity and 5-hydroxytryptoph may thus control the rate of metabolism of 5-hydroxy tryptamine. 'We have inferred by our experiments that 5-hydroxytryptophan leads to an inhibition of gastric secretion due to its conversion to 5-hydroxytryptamine by a mechanism such as this.

$$
\begin{array}{ll}
\text { Department of Surgery, } & \text { A. N. Smith } \\
& \text { J. W. Black } \\
\text { E. W. Fisher }
\end{array}
$$

Department of Veterinary Physiology,

$$
\text { University of Glasgow. }
$$

${ }^{1}$ Proceedings of International Symposium on H', London, Aprit
1957 (to be published by Pergamon Press). 2 Dalgliesh, C. E., and Dutton, R. W., Biochem. J., 65, 21 P (1957).

\section{Occurrence of an Amine Oxidase in Horse Serum}

Much work has been done on the intracellular amine oxidase, a mitochondrial enzyme widely distributed in vertebrate and invertebrate tissues. This enzyme is a catalyst of the biological inactivation of 5-hydroxytryptamine and of the sympathomimetic amines.

In recent years another enzyme has been described in the blood plasma of ruminants which acts mainly on spermine and spermidine, substances which are not oxidized by the intracellular amine oxidase. The spermine oxidase acts slowly also on many amines which are substrates of the intracellular oxidase ${ }^{1,2}$.

We have now made observations on a new type of amine oxidase which occurs in horse serum. Horse serum is without significant action upon spermine and spermidine, but we have found that it oxidizes many amines, some rather slowly. These amines include 5-hydroxytryptamine, a number of sympathomimetic amines, cystamine and homocystamine,

\begin{tabular}{|c|c|c|c|c|c|c|c|c|c|c|c|}
\hline & \multirow{3}{*}{$\begin{array}{l}\text { Exp. } \\
\text { No. }\end{array}$} & \multirow{3}{*}{$\begin{array}{c}\text { Dog } \\
\text { weight } \\
\text { (kgm.) }\end{array}$} & \multirow{3}{*}{$\begin{array}{c}\text { Dose 5-Htp } \\
(\mu \mathrm{gm} . / \mathrm{kgm} . / \mathrm{min} .)\end{array}$} & \multicolumn{8}{|c|}{ Histamine $5 \mu \mathrm{gm} . / \mathrm{kgm} . / \mathrm{min}$. intravenously, throughout } \\
\hline & & & & \multicolumn{8}{|c|}{ Time in consecutive $\frac{1}{2}$-hr intervals } \\
\hline & & & & 1 & 2 & 3 & 4 & 5 & 6 & 7 & 8 \\
\hline \multirow[t]{2}{*}{$\stackrel{(a)}{\text { Control group }}$} & $\begin{array}{l}1 \\
2 \\
3\end{array}$ & $\begin{array}{l}25 \\
12 \\
15\end{array}$ & - & $\begin{array}{l}0 \cdot 39 \\
0 \cdot 03 \\
0 \cdot 13\end{array}$ & $\begin{array}{l}2 \cdot 34 \\
1 \cdot 25 \\
0 \cdot 42\end{array}$ & $\begin{array}{l}3 \cdot 03 \\
2 \cdot 41 \\
0 \cdot 95\end{array}$ & $\begin{array}{l}2 \cdot 46 \\
2 \cdot 42 \\
1 \cdot 11\end{array}$ & $\begin{array}{l}2 \cdot 64 \\
2 \cdot 42 \\
1 \cdot 20\end{array}$ & $\begin{array}{l}2 \cdot 75 \\
2 \cdot 45 \\
1 \cdot 28\end{array}$ & $\frac{2 \cdot 76}{1 \cdot 16}$ & $\frac{2 \cdot 75}{-\cdots}$ \\
\hline & & & & \multicolumn{3}{|c|}{ 5-Hydroxytryptophan } & \multicolumn{3}{|c|}{$\begin{array}{c}\text { Infusion } \\
\text { 5-Hydroxytryptophan }\end{array}$} & & \\
\hline$\stackrel{(b)}{\text { Experimental group }}$ & $\begin{array}{l}1 \\
2 \\
3\end{array}$ & $\begin{array}{l}15 \\
13 \\
18\end{array}$ & $\begin{array}{r}5 \\
10 \\
15\end{array}$ & $\begin{array}{l}0 \cdot 72 \\
1 \cdot 19 \\
1 \cdot 29\end{array}$ & $\begin{array}{l}1 \cdot 32 \\
2 \cdot 10 \\
1 \cdot 70\end{array}$ & $\begin{array}{l}0 \cdot 65 \\
0 \cdot 38 \\
0 \cdot 63\end{array}$ & $\begin{array}{l}1 \cdot 24 \\
0 \cdot 70 \\
1 \cdot 82\end{array}$ & $\begin{array}{l}0 \cdot 33 \\
0 \cdot 37 \\
2 \cdot 24\end{array}$ & $\begin{array}{l}0 \cdot 24 \\
0 \cdot 15 \\
0 \cdot 90\end{array}$ & $\begin{array}{l}0 \cdot 78 \\
0 \cdot 08 \\
0 \cdot 20\end{array}$ & $\overline{1 \cdot 30}$ \\
\hline
\end{tabular}
and some long-chain polymethylene diamines. All

Table 1. (a) Control Grodp given Histamine, to elicit Platead of Segretion ; $(b)$ Exphermental Grodp given Histame and 5-HXDROXYTRYPTOPHAN

(Figures are expressed as average acid output in m.eq./15 min. from two $15 \mathrm{~min}$. collections) 